\title{
NOTES
}

\section{ANTIBIOTICS FROM MYCOPLASMA. I} ACHOLEPLASMA LAIDLAWII B

\author{
D. Perlman, Carl C. Fraterrigo \\ and J. L. Schwartz \\ School of Pharmacy, \\ University of Wisconsin, \\ Madison, Wisconsin, U.S.A.
}

(Received for publication June 19, 1972)

In the course of our studies on mechanisms of antibiotic resistance in Mycoplasma ${ }^{1,2)}$ we noted that under certain conditions Acholeplasma laidlawii B produced an antibiotic substance ${ }^{3)}$. Further investigation of conditions favoring the production of this material and the identity of the substance(s) was relatively inconclusive as $A$. laidlawii $B$ was erratic in producing this antibiotic.

However, the tetracycline-resistant mutant mentioned earlier ${ }^{2)}$ appeared to be more consistent in antibiotic production even though $95 \%$ of the fermentations did not show any antibiotic potency by the bioassay methods used.

Best results were obtained when the $A$. laidlawii B mutant was grown in Difco PPLO broth (without crystal violet) supplemented with bovine serum, sodium acetate, and Difco yeast extract. The serum level could be varied from 0.1 to $10 \%$ without variation in antibiotic production, and swine and horse serum could be substituted for the bovine serum component. Best results were obtained when static culture was used (100 $\mathrm{ml} / 250 \mathrm{ml}$ cotton-plugged Erlenmeyer of $500 \mathrm{ml} / 1,000 \mathrm{ml}$ Erlenmeyer) and the cultures were incubated at $37^{\circ} \mathrm{C}$. No correlation between antibiotic production and growth was noted (SMrri's method was used for measuring growth, e.g. increase in colony forming units ${ }^{4}$, and antibiotic production was independent of incubation period. In the 'active' preparations, antibiotic production phase lasted for less than 24 hours.

Antibiotic production was measured by agar-diffusion assays using the inhibition of Bacillus subtilis Marburg. One unit of antibiotic activity has been defined as that amount of material required to produce an inhibition zone of $22 \mathrm{~mm}$ in diameter when the antibiotic solution is placed in a $10 \mathrm{~mm}$ well in a $100 \mathrm{~mm}$ Petri dish containing $10 \mathrm{ml}$ of Penassay ${ }^{\mathrm{R}}$ agar seeded with $B$. subtilis spores. The most potent fermentation contained 4 units per $100 \mathrm{ml}$ of broth.

Recovery of the antibiotic material was accomplished by lyophilizing the fermentation and resuspending the solids in $1 / 20$ of the original volume of $50 \%$ ethanol. The undissolved solids were discarded, and the solution concentrated in vacuo and passed over columns of Dowex $50 \times 2$ and then Dowex $1 \times 2$ with $\mathrm{NH}_{4} \mathrm{OH}$ as eluting solution for the first and water for the second column. This procedure resulted in about 8 -fold purification and loss of about $50 \%$ of the activity.

The purified material contained 3 bioactive substances as shown by paper chromatography $\left(n-\mathrm{BuOH}-\mathrm{E} \mathrm{tOH}-\mathrm{H}_{2} \mathrm{O}, \quad 2: 1: 1\right)$ followed by bioautography against $B$. subtilis. The bioactive mixture was stable to heating at $100^{\circ} \mathrm{C}$ for 15 minutes over the $\mathrm{pH}$ range 2 to 9 . It was not inactivated by Nagarse ${ }^{R}$ ( $1 \mathrm{mg}$ enzyme/unit of antibiotic) at $\mathrm{pH} 7.5$ with an incubation period of 3 days at $37^{\circ} \mathrm{C}$.

The bioactivity was found to be limited to certain Gram-positive bacteria including B. subtilis Marburg (spores and vegetative cells), Bacillus megaterium, Staphylococcus aureus FDA 209P, and S. aureus 1206 (a tetracycline-resistant clinical isolate). No inhibition was observed at levels tested of Sarcina lutea, Escherichia coli, Saccharomyces cerevisiae, A. laidlawii $\mathrm{B}$, or mammalian cells in tissue culture (EAGLE's KB, EARLE's $\mathrm{L}_{929}$, or Gex's HeLa). A B. subtilis mutant with induced resistance (25 times m.i.c.) was found as sensitive as the parent culture to: ampicillin; penicillin G; streptomycin; tetracycline; erythromycin; neomycin; novobiocin; lincomycin; capreomycin; mikamycins $A+B$; staphylomycins $\mathrm{S}+\mathrm{M}$; and chloramphenicol. 
The mechanism of action of the A. laidlawii $\mathrm{B}$ antibiotics appears to involve inhibition of protein synthesis as determined by studies involving the incorporation of $\mathrm{L}-$ leucine ${ }^{14} \mathrm{C}$, uridine $-5-{ }^{3} \mathrm{H}$ and thymidinemethyl $1{ }^{3} \mathrm{H}$ by whole cells of $B$. megaterium, and cell-free protein synthesis using $E$. coli $\mathrm{B}$ ribosomes with polyuridylic acid as messenger. The antibiotics are bacteriostatic at the m.i.c. for B. subtilis (0.066 units $/ \mathrm{ml})$.

Further evaluation of the antibiotics in vitro and in vivo will depend upon availability of active fermentations.

\section{Acknowledgements}

This investigation was supported by a grant from the Schering Corporation and by the Public Health Research Grants AI-09320 and AI-10505 from the National Institute of Allergy and Infectious Diseases.

\section{References}

1) Fraterrigo,C.C. \& D.Perlman : Tetracycline inhibition of Mycoplasma ribosomal protein synthesis. J. Antibiotics $24: 185 \sim 188,1971$

2) Schwartz, J. L. \& D. Periman : Antibiotic resistance mechanisms in Mycoplasma species. J. Antibiotics $24: 575 \sim 582,1971$

3) Schwartz, J. L. : Antibiotics and Mycoplasma. Ph. D. Thesis, University of Wisconsin-Madison, 1971

4) Sмгтн, P. F. : Quantitative measurement of the growth of pleuropneumonia-like organisms. Appl. Microbiol. $4: 254 \sim 259,1956$ 